\title{
Students' Voice: A Need Analysis on Teaching and Learning English at Islamic University
}

\author{
Alfian, alfian@uinjambi.ac.id, State Islamic University STS Jambi, Indonesia
}

\begin{abstract}
This paper provides a detailed description of the need analysis for designing English teaching and learning activities for non-English major learners. This case study research highlights the need analysis for English teaching and learning by involving students of Tarbiyah and Teacher Science Faculty at one of Islamic University in Indonesia. The data were collected by conducting Focus Group Discussion (FGD) and survey. Thematic methods analyzed the data from FGD, and the survey data were analyzed using Microsoft Excel. It was found that speaking and developing vocabulary are the most important language skills and components to be improved. The result also indicated that various activities should be implemented in the classroom, such as a game, pair works, and group discussion and presentation. Furthermore, improving four language skills and vocabulary was the target of learning English. This study is crucially important for the process of teaching and learning English and for designing curriculum and course delivery of English for non-majoring students.
\end{abstract}

Keywords: Need analysis, ESP, language skills, language components

\section{INTRODUCTION}

A successful learner is not the one who instantly master the language by her/himself and picks up the language easily from the learning process in the classroom, however, mastering and picking up the language from the teaching and learning process are influenced by a lot of factors, such as teacher, learning materials, teaching methods, learning strategies, learning environment, and learner's need. Learners often neglected these factors, s a result, the success in language learning could not be achieved. However, the involvement of the above factor needs to be investigated in a particular context to optimize learning opportunities in learning English for Academic Purposes (EAP) and English for Specific Purposes (ESP). The purpose of investigating these factors is in two folds. First, it is to see whether the goal of learning is achieved. Second, it is to see whether the students fulfill their need for learning.

Within the Indonesian context of English learning, especially at Islamic institutions, it is considered that the present material, student activities in learning, and teaching methods used by the teacher have not yielded the desired results of learning English and have not addressed the learners' both professional and academic goal. This situation happens because teaching materials, especially for the non-English major learner, are mostly in the form of handouts and sheets of paper and developed into the powerpoint. They collected many different sources, such as a book and internet (Rizal, S, 2019; Yaumi, M, 2012). These learning materials may not fulfill the need of the student because what the students need may not cover in the material, whereas learning material is the crucial thing in the teaching and learning process (Rohmah, Z, 2015). Besides, learning material, the teaching methods, and other learning activities do not encourage the learners to learn. This situation happens because it seems that need analysis was absent (NA) before preparing the teaching and learning activities. Thus, formal needs analysis procedures for teaching and learning activities and processes are urgently required to meet the needs of a target group of learners (Chostelidou, 2010). 
It is important to note that needs analysis is the foundation of creating a "focused course" (Dudley-Evans T \& Saint John, M. J, 1998). Furthermore, need analysis is used as the foundation in designing tests, evaluating teaching strategies, designing teaching materials, designing teaching, and learning activities (Diana and Mansur, 2018). Thus, Need Analysis (NA) is important to make the teaching and learning activities run well and to fulfill the student's needs. As a result, their motivation to study raise (Yaumi, 2012).

Need Analysis (NA) is the process of collecting information from the learners about what needs to be taught and learned by the learners for the course. NA is the identification of what is needed by the learner in learning the lesson (Sholikhah, 2016). Previously, Richards (2001) emphasized that need analysis refers to"the procedures and activities that collect information about students' needs, then validate and prioritize those needs to be the foundation for designing and evolving a curriculum that matches those needs. In this definition, it was emphasized that every learner has their different needs, and what is taught must match the learner's needs. From this definition, it is clear that the benefit and function of need analysis are apparent: Need analysis is needed for determining the success of learning (Richards, 2002). NA is also to see the accuracy and suitability of learning programs, such as curriculum and the situations where English is used. Therefore teachers would be considerably easy in designing learning materials and textbooks for fulfilling the needs of students (Kusumaningputri, 2011). Furthermore, Richards (2013) emphasized that the learning objectives are depending on the system analysis or need analysis is part of the proses in determining learning aims and objectives. NA is also tremendously important to consider to meet academic requirements and satisfy the specific needs of students (Nurie, 2017).

Sholikhah (2016) emphasized that need analysis could be done through Identifying the learner's communicative need, determining general and specific objectives, determining the content of learning material and the language skills, arranging the outline of the material in the form of the syllabus and selecting teaching material and appropriate teaching methods. Adhabiyyah (2014) stated that there are three components of NA, which are "Target analysis, current situation analysis, and teaching and learning situation analysis." English for specific purposes (ESP) has a difference from General English. According to Robinson (1990), the main goal of ESP is to master English in the learners' field of study. Thus, the ESP curriculum and its syllabus should be designed to be learner-centered. It is related to the terms used or the vocabulary and the type of discourse that is or the type of conversation that usually occurs in different disciplines (Hutchinson \& Waters, 1987). For example Chemistry students, then they should have to acquire materials and understand English for Chemistry, or if they are students of Islamic Religious Education, they should know English terms related to Islamic Education, if they are economics students, economic terms in English.

Similarly, Donough (1984) states that the communication need of the learners is prioritized by syllabus and materials. Donough (1984) suggests that objectives, syllabus, and the material of ESP should be developed and designed based on the students' needs and the "graduate users." So ESP is a special approach that is bottom-up in learning. ESP refers to focused learning, which is oriented to the specific field in English. It is focused on the sciences and the field of the work of the graduate. In order to implement English as a specific objective, it is necessary to have the right teaching material because the teaching material has a crucial role in determining the success of learning (Harmer, 2009; Hutchinson \& Torres 1994; Cunningsworth 1995; Richard 2001; and Karomouzian 2010). Thus, non-English major learners should have different purposes for learning English. It is essential to place ESP as a tool for Islamic university students to support their studies. The emphasis on teaching English on content and learning materials demands the need for the development of good teaching materials. 
Most studies on need analysis of language skills conducted by the researchers all over the world (Aeni N, Jabu B, Rahman M. A, Ismail H, \& Bin-Tahir S. Z, n.d.; Alqunayeer \& Zamir S, 2016; Bae D, 2017; Diana S \& Mansur M, 2018) found that Speaking skills was given to be the highest consideration to be improved and the top one in their list for making improvement. For example, Boroujeni and Fard (2013), who conducted a need analysis study in Iran, found that speaking was to be the first rank in the list needed by the learners. These findings indicated that the student's main purpose in learning English is to communicate in English, and students believed that learning a language should be started by using it in speaking (Poedjiastutie \& Oliver 2017). Furthermore, speaking skill is also believed as the basic in language skill for making interaction with other speakers (Abrar, 2018). However, some studies demonstrated a different finding. For example, Luankanokrat (2011) in Thailand found that reading was the most important skill needed by the learners, and speaking skill was the least one. This study, similar to the finding of the study conducted by Wu \& Lou (2018). Their finding revealed that reading skills were the most needed by the students who learn English for Specific Purposes ( ESP). Different from previous studies, Aklilu (2015) showed that writing skills and subskills were most needed by civil engineering students, followed by reading and speaking skills in Ethiopia.

Besides the importance of speaking skills, improving vocabulary was another concern of the learners. Studies indicated that acquiring vocabulary were also the special concerns of learners (Evan, S \& Green, C, 2007; Hyland, K, 1997; Jalil, N \& Kamarudin, M, 2009; Littlewood, W \& Liu, N, 1996). Kaur et al. (2013) also found that vocabulary development is also one of the most important activities to be improved. This finding is supported by Diana and Mansur (2018), which found that improving vocabulary is given the highest priority among grammar and pronunciation. These findings support that to speak English well, and a learner should have a great number of vocabulary, which is around 3000-5000 vocabularies (Nurweni and Read, 1999).

Another concern of the studies on need analysis is varieties of learning activities, learning strategies, and teaching methods. Aeni, et al. (2018) found that varieties of learning activities and teaching methods need to be implemented in teaching and learning. This finding also supported by a study Boroujeni and Fard (2013) which shows that student likes active roles in the classroom. Diana and Mansur (2018) found that students prefer to have learning activities by the oral report, role play, game, and out of Class activity. However, it is reported that Roleplay $(50 \%)$ was the most favored learning activity chosen by the participant. In terms of learning strategies, most studies found that language learners have used a variety of strategies in learning English (Alfian 2018; Annurahman et al. 2013; Hayati 2015; Kartika and Emaliana 2016; Idham 2014).

In light of all the empirical evidence reported above and the literature reviewed on the role of needs analysis for the success of English learning, the researcher proposed that it is tremendously important to consider learner needs analysis to meet academic requirements and satisfy the specific needs of students in a certain context of study because NA is defined as context-specific (Ferris 1998). Therefore, a similar study on the need analysis in a certain context such as at the Islamic Higher Education Institution is urgently needed in order to hinder the discrepancies between students' language learning needs and issues on English instruction and delivery in the global perspectives. The results of the need analysis of the present study could be used by the lecturer in designing English teaching material and activities for non-English majors.

This paper presents the results of a current study on need analysis related to learning purposes and learning outcomes, language learning materials, teaching techniques, and students` learning strategies of non-English majors. This need analysis is required to obtain 
information about the students' needs used for developing teaching and learning activities. This need analysis is theoretically very useful as an input in the development of teaching and learning activities, developing textbooks related to English for Islamic religious majors. Practically this research will be eventually important for an English lecturer and students, especially students learning strategies.

\section{METHODS}

A case study method employing both qualitative and quantitative techniques of data collection was adopted in this research. Thus, the data were collected by distributing a questionnaire to 456 participants at the Faculty of Tarbiyah of State Islamic University. The participants, as the population, was chosen by employing a purposive sampling technique. Therefore, the population of this study was in the 1 st and 3rd semester. The selection of the third semester was that because they have taken English subjects, and the 1st was taken as a population because they were taking this subject. The questionnaire Another method of data collection was done by conducting a focus group discussion. The focus group discussion was conducted with four groups of students in which each group consists of 5 participants. Forty students to answer research questions related to the strategy used and the teaching method used by the teacher. The descriptive and frequences analysis were employed to analyzed that data from the questionnaire and focus group interviews were analyzed by using thematic methods of data analysis, including coding, categorizing, and emerging themes (Braun and Clarke 2006; Fielding 2008; Miles and Huberman 1994; Seale 2004).

\section{RESULTS}

The results of the study are presented based on the research questions which are focused on the learning purpose, learning material, and teaching methods, and learning strategies.

The first research question of the study is about learning objectives and targets in learning English. The result of the analysis is presented in table 1 below.

Table 1. Learning objectives and outputs

\begin{tabular}{llll}
\hline No & Statements & Choice & Percentage \\
\hline \multirow{2}{*}{$\begin{array}{l}\text { Purpose of } \\
\text { learning }\end{array}$} & Higher education & 10,29 \\
\cline { 3 - 4 } & & Future career & 34,56 \\
\cline { 3 - 4 } & Understanding text & 45,59 \\
\cline { 3 - 4 } & Other & 9,56 \\
\hline \multirow{2}{*}{ Target in learning } & Improving 4 skills & 60,47 \\
\cline { 3 - 4 } & & Pass TOEFL & 9,30 \\
\cline { 3 - 4 } & & Improved grammar & 0 \\
\cline { 3 - 4 } & & Improved vocabulary & 30,23 \\
\cline { 3 - 3 } & &
\end{tabular}

Table 1 above indicated that the majority of the students $(45,9 \%)$ believed that understanding English text is the main objective for studying English at the university level. Besides understanding the English text, Success for a future career $(34,56 \%)$ is the student's main dream in learning English. The other 10\% of the students believed that learning English is one of the requirements for pursuing higher education, while $9.6 \%$ of the students have other goals for learning English. 
Related to learning targets, the majority of the learners $(60,47 \%)$ expected to improve the four language skills (Listening, Speaking, Reading, Writing). This finding shows that four language skills are very vital things in learning a language. Furthermore, the second highly desirable output in learning English is to increase vocabulary (30.23\%). This finding supports the finding of other studies (Hyland, 1997. Jalil \& Kamarudin, 2009; Littlewood \& Liu, 1996; Evans \& Green, 2007). These studies show that vocabulary acquisition was the most concern of the students. This concern is very reasonable because to communicate well in English, and a learner should have around 3000- 5000 vocabularies (Nurweni, A \& Read, J, 1999). Interestingly, students do not have a target to improve their grammar in learning English.

The finding of this study is very synchronous with the objective of the learners in which to understand English text, so it cannot be questions that the target is to improve their language skills and enrich the vocabulary. This finding means that the lecturers need to design the lesson, which emphasizes on four language skills and vocabulary enhancement.

The result of data analysis of student surveys related to the importance of language skills and components consists of 2 parts, namely: The language skills and language component, such as Grammar and vocabulary needed by students, which are presented in table 2 below.

Table 2. Language skills and components and type of English material

\begin{tabular}{llll}
\hline 1 & $\begin{array}{l}\text { Language skills and } \\
\text { language component }\end{array}$ & Listening & 8,57 \\
\cline { 3 - 3 } & Speaking & 42,86 \\
\cline { 3 - 3 } & & Reading & 2,86 \\
\cline { 3 - 3 } & Writing & 11,43 \\
\cline { 3 - 3 } & Vocabulary & 28,57 \\
\cline { 3 - 3 } & Grammar & 5,7 \\
\hline 2 & Type of Teaching Material & General English & 67,18 \\
\cline { 3 - 3 } & & Esp & 32,06 \\
\cline { 3 - 3 } & Others & 0,76 \\
\hline
\end{tabular}

Table 2 demonstrates that the majority of students believed that speaking skills $(42,86 \%)$ are the most essential skill, while Vocabulary development $(28,57 \%)$ is the most important language component to be developed. Therefore, speaking and developing vocabulary must be the focus of the lecturer in developing learning material and making activities for students. However, it can be concluded that students are convinced that all language skills and components need to be taught into language learning materials. This finding is in line with other studies (Alqunayeer \& Zamir S, 2016; Bae D, 2017), indicating that speaking skill was the most favored skill chosen by the participants. The reason why students prioritize Speaking skill is that they need for communication. This finding also assumed that students believed that by improving their speaking skills and increasing their vocabulary, learners would be able to communicate in English by the objectives of learning English, which is to be able to communicate well in English both oral and written (Permendikbud, 2013).

. From table 2 above, it can be seen that almost $67 \%$ of students believed that the content of English teaching materials for students of the first semester is general English. This opinion confirms that the basic English subject, according to the student, is to be general English. This means that from the beginning, learning should get basic English before moving on to the next English that suits their department. Meanwhile, 32.06\% stated that the content of English learning materials should be under their majors $(32,06 \%)$. While 0.76 students 
have not been very familiar with what material should be included in English learning materials.

These significant findings on learning materials suggest that both language skills and language components (vocabulary and grammar) should be included in learning material and activities, which can language skills and vocabulary and grammar enhancement.

According to these findings, lecturers must formulate a good learning syllabus that covers all language skills and language components, particularly speaking and vocabulary improvement. In other words, the syllabus should be implemented by designing the Semester Learning Plan (Rencana Pembelajaran Semester/RPS). Furthermore, the teaching and learning process should use appropriate teaching materials, such as textbooks, modules, and handouts. These teaching materials should also be designed at least through 4 stages: (1) the stage of designing the learning objectives, (2) the stage of designing the learning materials, (3) the stage of designing the strategy learning, and (4) the design stage of learning evaluation (Rizal, 2019).

The findings from the interviews referred to the lecture teaching techniques, activities, and student learning strategy that can be seen in Table 3 below.

Table 3. Teaching techniques and learning strategies

\begin{tabular}{ll}
\hline 1 Teaching techniques & More game \\
and activities & Relax and happy \\
& Using song \\
& Question and answer \\
& explanation \\
& using English \\
& Teaching more vocabularies \\
& Asking students to practice \\
& Presentation \\
& Lecture \\
& Pair work \\
& Group discussion \\
& Individual presentation \\
\hline Learning strategies & Watching movie \\
& Memorizing vocabularies \\
& practicing \\
& writing \\
& speaking \\
& reading article, novel, story \\
& Repetition \\
& using youtube \\
& listening to music \\
& question and answer \\
make humor \\
Taking English Course \\
imitating \\
game \\
using social media \\
pronouncing the words \\
\end{tabular}


The findings of lecturer teaching techniques and activities are various. As can be seen from Table 3 above that there are a lot of teaching techniques and learning activities suggested by the learners. For example, an English lecturer should be able to create a good class atmosphere that varies and fun. This technique can be done with questioning, asking/reproducing students to practice, sufficient - explanations/ presentations from classroom lecturers, making games, and other activities that can add their vocabulary.

These teaching techniques and classroom activities are also in line with the survey of language learning strategies proposed by the students. The results show (see table 3 above) the various ways or strategies undertaken by students in improving their English skills. More than ten strategies or ways they do in improving their English are among the most important and appropriate teaching methods they expect to practice English, practice four language skills, and memorize or add to their vocabulary. Besides, to improve their English, they use media and technology, such as TV, tape recorder, social media like Youtube and Facebook. The students use various ways to improve their English language ability. This finding supported the previous studies on language learning strategies which were indicated that good learner uses many strategies in learning (Alfian A, 2018; Annurahman, Kurniawati, \& Ramadhiyanti Y, 2013; Hayati, N, 2015; Idham, S, 2014; Kartika, T \& Emaliana, L, 2016). The variety of strategies of students is closely related to "strategy awareness" or awareness in searching for strategies to improve the student's overall ability. (Lee \& Oxford, 2008) emphasized that strategy awareness or awareness about the importance of strategy greatly helps language learners use these strategies. This strategy will bring the student into a good learner.

\section{CONCLUSION}

The findings from the data analysis have demonstrated several issues related to the need of the learners need in learning. These issues need to take account because they provide important implications for improving teaching and learning in English and the changing of the curriculum of English for no English major.

First, the finding indicated that the main objective of learning is to understand the text in English of their major. This finding means that there is a call for a highly specific syllabus, which is emphasized reading comprehension and vocabulary enrichment on their major.

Second, the finding demonstrated that all four language skills are essential for learners. Thus, it is needed to set up the course and the learning material with a clear focus on 4 English skills, especially speaking skills and vocabulary development. It is also suggested that the activities, such as making a presentation, public speaking, independent task on vocabularies enrichment should be included in the syllabus designed both for in-class and out of class activities. This will encourage the students to be autonomous learners.

Third, in terms of teaching methods and learning activities, most participants agree that the teaching method and learning activities should have variations. This is to accommodate the participants who have different strategies concerning the approach of learning.

Fourth, the analysis of student needs in this study is expected to provide a reference for lecturers to develop language teaching language. This need analysis also provides a call for a highly specific syllabus which is needed to be designed, which emphasizes both the receptive and productive skills and language components. As a result, the needs syllabus document is expected to reflect the student's need by using authentic material because it was felt that the current English syllabus and material used by the lecturer are not at all matched with the student's need. 
Finally, this study has limitations in terms of population and sample in which there were only two study programs are in close consultation. Further research is expected to involve more study programs so that the data can be crossed checked.

\section{REFERENCES}

Abrar, M. (2018). An Investigation Into Indonesian EFL University Student' Speaking Anxiety. JEELS (Journal of English Education and Linguistics Studies), 221-248.

Adhabiyyah, R. Mahanum, \& Nor A.M. (2014). Needs Analysis and Material Development in English for Specific Purposes in Relation to English for Islamic Studies. E-Proceedings of the Conference on Management and Muamalah, 26-27.

Aeni N, Jabu B, Rahman M. A, Ismail H, \& Bin-Tahir S. Z. (n.d.). The Students' Needs in Maritime English Class at Ami Aipi Makassar, Indonesia. Journal of Language Teaching and Research, 1284-1292.

Ahmed Alsamadani, H. (2017). Needs Analysis in ESP Context: Saudi Engineering Students as a Case Study. Advances in Language and Literary Studies, 8(6), 58. https://doi.org/10.7575/aiac.alls.v.8n.6p.58

Alfian A. (2018). Proficiency level and language learning strategy choice of Islamic University learners in Indonesia. TEFLIN Journal, 1-18.

Alqunayeer, \& Zamir S. (2016). Needs Analysis of Saudi EFL Female Students: A Case Study of Qassim University. Journal of Curriculum and Teaching.

Annurahman, Kurniawati, \& Ramadhiyanti Y. (2013). Exploring Indonesian college students' strategies in Learning English Language. AWEJ. 317-330. https://doi.org/10.26858/eltww.v4i1.3209

Bae D. (2017). Designing an English Syllabus for Nursing Students based on need analysis in Indonesia. ELT WORLDWIDE, 4(1), 87-104.

Braun, V., \& Clarke, V. (2006). Using thematic analysis in psychology. Qualitative Research in Psychology, 3(2), 77-101. https://doi.org/10.1191/1478088706qp063oa

Chostelidou, D. (2010). A needs analysis approach to ESP syllabus design in Greek tertiary education: A descriptive account of students' needs. Procedia - Social and Behavioral Sciences, 2(2), 4507-4512. https://doi.org/10.1016/j.sbspro.2010.03.721

Diana S, \& Mansur M. (2018). Need Analysis of English Teaching Materials for ICT Students. ETERNAL (English, Teaching, Learning, and Research Journal), 4(3).

Donough, J. (1984). ESP in Perspective A Practical Guide. London: Collin ELT.

Dudley-Evans T, \& Saint John, M. J. (1998). Developments in English for specific purposes: A multi-disciplinary approach. Cambridge university press.

Dudley-Evans, T, \& St John, M. (1998). Developments in English for specific purposes- a multi-disciplinary approach. London: Cambridge University Press.

Evan, S, \& Green, C. (2007). Why EAP is necessary: A survey of Hong Kong tertiary students. Journal of English for Academic Purposes, 6(1), 3-17.

Ferris, D. (1998). Students' views of academic aural/oral skills: A comparative needs analysis. TESOL Quarterly, 32(2), 289-318.

Fielding, J. (2008). Coding and managing data. In G. N (Ed.), Researching social life. London: Sage Publication Ltd.

Goto-Tamura, R., Takesue, Y., \& Takesue, S. (1976). The immunological similarity between NADH-cytochrome b5 reductase of erythrocytes and liver microsomes. Biochimica Et Biophysica Acta, 423(2), 293-302. https://doi.org/10.1016/0005-2728(76)90186-9

Harmer, J. (2009). The practice of English Language Teaching. Edinburgh: Pearson Education Limited. 
Hayati, N. (2015). A Study of English Language Learning Beliefs, Strategies, and English Academic Achievement of the ESP Students of STIENAS Samarinda. Dinamika Ilmu, 15(2), 297-323.

Hutchinson, T, \& Torres, E. (1994). The textbook as an agent of change. ELT Journal, 48(4), 315-328.

Hyland, K. (1997). Language attitudes at the handover: Communication and identity in 1997 Hong Kong. English World-Wide, 18(2), 191-210.

Idham, S. (2014). Language Learning Strategies: Gender and Proficiency. Marwah: Jurnal Perempuan, Agama Dan Gender, 13(1), 104-131.

Jalil, N, \& Kamarudin, M. (2009). ELAP needs analysis for law students. Journal of Human Capital Development, 2(2), 121-136.

Karamouzian, F. (2010). A Post-Use Evaluation of Current Reading Comprehension Textbooks Used in TEFL Programs. The Iranian EFL Journal, 6(4), 24-62.

Kartika, T, \& Emaliana, L. (2016). Students' Achievements and Learning Strategies Across Gender Differences. JEELS (Journal of English Education and Linguistics Studies), $3(2)$.

Kaur, N. (2013). The need for autonomous vocabulary learners in the Malaysian ESL classroom. GEMA Online: Journal of Language Studies, 13(3).

Kusumaningputri, R. (2011). Needanalysis dalam Mata Kuliah 'English For Specific Purposes".' Jurnal Pengembangan Pendidikan, 8(2).

Littlewood, W \& Liu, N. (1996). Hong Kong students and their English. Macmillan Publishers Limited.

Luankanokrat, S. (2011). Needs analysis for English communication skills of employees at HSBC in Thailand. Language Institute Journal.

Mahbub, M. (2019). English Teaching in Vocational High School: A Need Analysis. JEELS (Journal of English Education and Linguistics Studies), 5(2), 229-258.

Munby, J. (1978). Communicative Syllabus Design. Cambridge: Cambridge University Press.

Nurie, Y. (2017). Analyzing the English Language Needs of University Law Students. The Internet Journal Language, Culture, and Society.

Nurweni, A, \& Read, J. (1999). The English vocabulary knowledge of Indonesian university students. English for Specific Purposes, 18(2), 161-175.

Permendikbud. (2013). Permendikbud nomor 64 tahun 2013 tentang Standar isi. Jakarta: Badan Standar Nasional Pendidikan.

Poedjiastutie, D, \& Oliver, R. (2017). English Learning Needs of ESP Learners: Exploring Stakeholder Perceptions at An Indonesian University. TEFLIN Journal, 28(1), 1-21.

Richard, Jack C. (2001). Curriculum Development in Language Teaching. Cambridge: Cambridge University Press.

Rizal, S. (2019). Analisis Kebutuhan Bahan Ajar Bahasa Inggris IAIN Bengkulu Melalui Students' Need Analysis. At-Ta'lim: Media Informasi Pendidikan Islam, 12(2), 232252.

Robinson, Paulina. (1990). English for Specific Purposes. Oxford: Oxford: Pergamon Press, Ltd.

Rohmah, Z. (2015). EFL Materials in Madrasah Tsanawiyah: What Do They Really Need? TEFLIN Journal, 20(1), 104-117.

Seale, Clive. (2004). Coding and Analysing data In C. Seale. London: Sage Publication Ltd.

Solikhah, Imrotus. (2016). Pengembangan model kurikulum pendidikanbahasa Inggris berbasis KKNI. Konstruktivisme, 8(1).

Tseng, S. (2012). The factors cause language anxiety for ESL/EFL learners in learning speaking. WHAMPOA-An Interdisciplinary Journal, 63(1), 75-90. 
Tsiplakides, I. (2011). Selecting an English Coursebook: Theory and Practice. Theory and Practice in Language Studies, 1(7), 758-764. https://doi.org/10.4304/tpls.1.7.758-764

$\mathrm{Wu}, \mathrm{J}, \&$ Lou, Y. (2018). Needs Analysis of Chinese Chemical Engineering and Technology Undergraduate Students in Yangtze University in English for Specific Purposes. Creative Education, 9(15), 25-92.

Yaumi, M. (2012). Pengembangan bahan ajar Englis for specific Purpose berbasis TIK. Lentera Pendidikan, 15(2), 144-160. 